Research.

\title{
THE EFFECT OF GOOD CORPORATE GOVERNANCE ON TAX AVOIDANCE: EMPIRICAL STUDY OF THE INDONESIAN BANKING COMPANY
}

\author{
Waluyo \\ Mercu Buana University, Jakarta
}

\begin{abstract}
The purpose of this study aims to examine the effect of corporate governance on tax evasion. Corporate governance is proxied represented by the audit committee, the proportion of independent board of commissioners, institutional ownership and audit quality. Tax evasion is measured by the size of the gap of an effective tax rate. This study uses quantitative research design and data from the Finance Authority Service / OJK listed on the Indonesia Stock Exchange. By using purposive sampling in the observation period of 2013-2016, it has obtained 92 observations. The Data has been analyzed by using ordinary least square regression model. Regression results has identified that the proportion of independent board of commissioners and corporate performance have negatively affected tax evasion. Audit committees, audit quality and the size of company positively affected tax evasion. However, the institutional ownership has had no significant effect on tax evasion. These results have indicated that some of the mechanisms of corporate governance in Indonesia have been effective according to its function for the shareholders.
\end{abstract}

Keywords: tax avoidance, corporate governance, audit committee, the proportion of independent board of commissioners, ownership institutional, audit quality.

\section{INTRODUCTION}

Tax is the most important contribution of the country since it has been one of main resources of the government revenue (Mulyadi et al, 2014). For the companies tax is not only one of their responsibilities to their government but also as a burden for their company. Since tax is a burden for the company, therefore an effective tax management should have to be managed well. Tax management has picked the advantage of Loophole mentioned on Tax Law and Tax Regulation. Perception of these activities has varied depending on each individual interest. As a matter of fact, principally tax avoidance has been divided into two categories; acceptable tax avoidance and unacceptable tax avoidance.

Tax avoidance is a transaction scheme to reduce the tax amount by making use of the loophole of tax regulation in a country. And, tax evasion is a scheme to pay less amount of tax indebted by breaking the tax regulation illegally refers to marking up the cost fictitiously. Bank as a financial institution has the important role to improve the economy of a country. However, whenever the tax controlling has not been done properly, tax avoidance will happen.

The institutional investors have had a chance and ability to control the company, to make it right and to influence the management accordingly to avoid any opportunistic management. Shares owned by the director, independent director and the percentage of the biggest shareholders are having a significant connection with the aggressiveness of 
the company's tax (Timothy, 2010). Company management has tended to reduce the level of tax avoidance, but a significant connection between the total of the independent directors and the tax aggressiveness has not been figured out (Zhou, 2011).

A research about the connection between Good Corporate Governance and tax avoidance has given a different result. Because each person has had a different motivation factor and each country has been having a social and political diversity. Nevertheless, only a few of the research about the connection between Good Corporate Governance and tax avoidance has been conducted in Indonesia.

Good controlling of the company has also required a good organizing which is Good Corporate Governance management. Good Corporate Governance mechanism has described the relationship of all the participants in the company which has been directing the company's performance (Haruman and Tendi, 2008).

The main objective of Good Corporate Governance is generally related to the accountability, responsibility, mechanism of the company to ensure a good attitude of the company to protect the shareholders' requirements including the company's obedience to pay the tax. The structure of the ownership of the company has been an important role in the Good Corporate Governance related to tax avoidance. Expertise of the managers to execute a Good Corporate Governance is really expected to be able to run the company and to supervise it more effective, so that, tax avoidance can be more limited.

Based on the background issue, the problem of this study can be described by the following question: Is the Good Corporate Governance represented by the Audit Committee, Board of Commissioners, the Institutional Ownership and Audit Quality affecting Tax Avoidance Practices.

\section{THEORY AND HYPOTHESIS}

\section{A. Agency Theory}

The agency problem has come up when the objective of the agents is different from the principal' goals. Agency theory has put the managers of the company as the agents and the shareholders as the principal (Jensen and Meckling, 1976). Shareholders as the principals have delegated the managers to make any business decision. The agents are not always making decisions due to the principal's purpose. The principals have required the system how to run the company, so that Good Corporate Governance can be established accordingly.

\section{B. Tax Avoidance}

Executing a legal tax efficiency can be done by Tax Management. Minimizing tax obligation can be done by various executions. Tax avoidance can be conducted by (1) substantive tax planning which is transferring tax subject and tax object to tax haven or the government has given a special tax treatment; (2) Formal tax planning which is defending the economics substance from any transaction by choosing a formal transaction that can provide a lower tax requirement; (3) Anti tax avoidance regulation against the transfer pricing transaction, thin capitalization, treaty shopping and controlled foreign corporation (a specific anti avoidance rule and general anti avoidance rule, Darussalam and Septriadi, 2009)

\section{Good Corporate Governance}

The implementation of Good Corporate Governance can solve the problem of the opportunist behavior of the manager which is connected with Tax Avoidance. Corporate governance is a system how to control the company. Board of directors is responsible for the implementation of Good Corporate Governance (Davies, 2006).

\section{The Audit Committee}

Waluyo: The Effect of Good Corporate Governance on Tax Avoidance: Empirical Study of The Indonesian Banking Company 
In order to follow the principles of good corporate governance, a company is required to have an audit committee implementing the principles of responsibility and accountability that has been described by KNKG. BEl has asked all the companies have to create and to develop an audit committee lead by an independent commissioner. An audit committee is in charge of controlling the process of financial reporting and internal controller (Annisa, 2011). Board of commissioners are obliged to develop an audit committee consisting of at least 3 members appointed or dismissed by the board of commissioners and they are responsible to the board of commissioners as well (Pohan, 2008).

\section{E. The Structure of the Institutional Ownership}

The institutional ownership is referred to the company's shares belong to the institution or organization such as insurance company, banks, investment company and other institutional ownerships (Tarjo, 2008) The institutional ownerships have owned majority of the shares since they have had more resources than the other investors accordingly. (Kusumaningtias, 2012). The bigger the institutional ownership, the bigger authority of the owners to control the operational of the company. The institutional investor is enable to analyze the information and is having a strong motivation to control strongly the operational of the company.

\section{F. The Audit Quality}

An audit is a chain of process or a procedure to minimize an incompliance information happened between the managers and the shareholders using the independent party to perform an audit upon the company's financial statement (Indah, 2010) Report of the financial statement of tax audited will be used by the decision maker. Audit quality should have to be maintained by the auditor so that the decision makers have made the proper decision. The financial statement that has been audited by the Public Accountant Office such as The Big Four are having a certain quality since the auditors of The Big Four Public Accountant Office are well trained and understanding the related procedures, and they have had more accurate and effective audit program rather than the other Public Accountant Offices

\section{G. Hypothesis Development}

The better corporate governance, the more improvement of tax management will be. (Minnick and Noga, 2010)

Audit committee has significantly affected the earnings management (Antonia, 2008). The members of the audit committee are able to supervise the managers more properly.

Based on the aforementioned description, $\mathbf{H}_{\mathbf{1}}$ hypothesis has been determining Audit Committee has affected Tax Avoidance practices.

Referring to the perspective of agency theory, members of board of committees who are from the external company have the function to control the executives of the company. (Solomon, 2007) By using the agency theory approach, the roles of the independent commissioners are very important to improve the performance of the company (Minnick and Noga, 2010). Based on the aforementioned description, $\mathbf{H}_{2}$ hypothesis has been determining The Independent Board of Commissioners has affected Tax Avoidance practices.

In order to reduce the opportunist behavior, supervising of the institutional investor can direct the managers to focus only to the performance of the company (Cornet et Al, 2006). The amount of the institutional ownership can influence the Aggressive Tax policy. However, the bigger long-term shareholder ownership, the lesser Aggressive Tax Policy will be. (Kurana and Moser, 2009). Based on the aforementioned description, $\mathbf{H}_{3}$ hypothesis has been determining The Institutional Ownership has affected Tax Avoidance practices. 
Good quality of an audit can minimize tax avoidance practices (Dewi and Jati, 2014). The companies which have been audited by The Big Four Public Accountant Office have been proved that they have done relatively less tax avoidance than the companies which have been audited by other public accountant offices. (Asfiyati, 2012). Based on the aforementioned description, $\mathbf{H}_{4}$ hypothesis has been determining The Quality of an Audit has affected Tax Avoidance practices.

\section{H. Theoretical Framework}

The theoretical framework has examined the effect of audit committee, proportion of board of commissioners, institutional ownership, and audit quality upon tax avoidance practices at banking enterprises using the size and performance of the company as controlled variables.

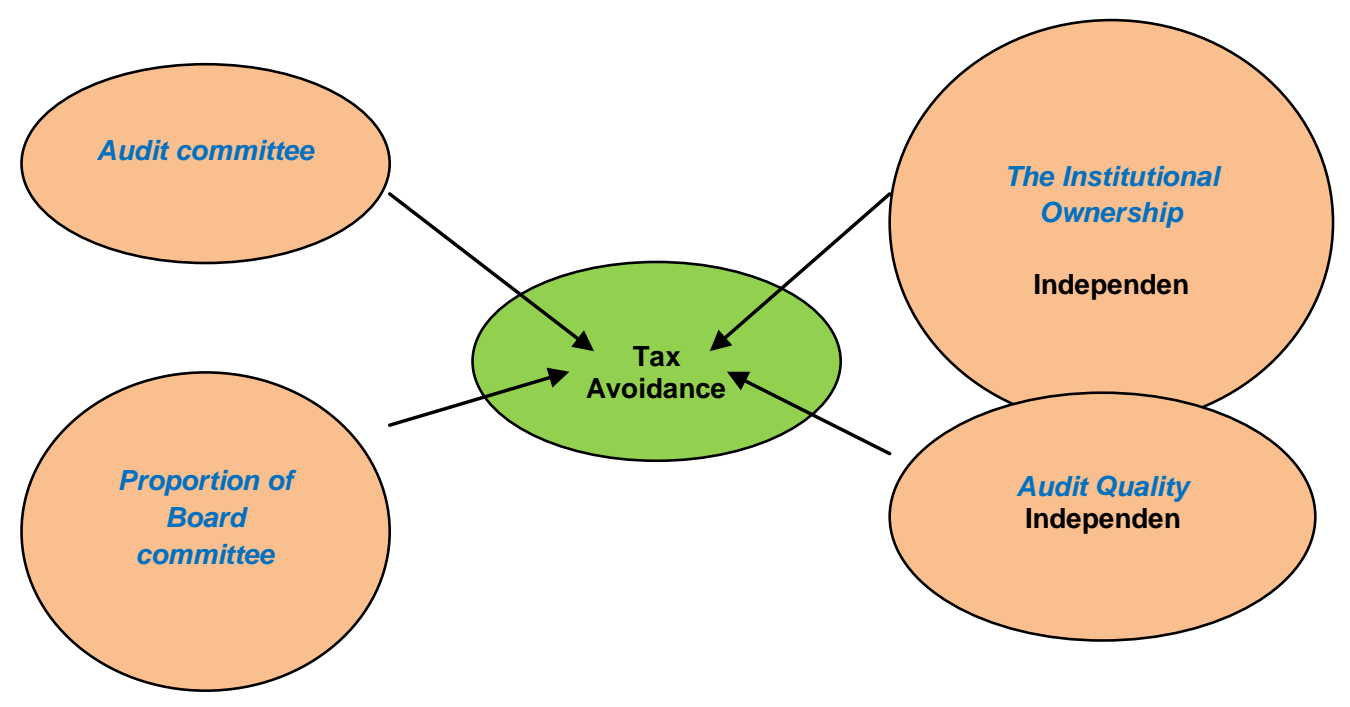

Figure 1. Theoretical Framework

\section{RESEARCH METHODOLOGY}

Is the research which aims to test a hypothesis or to test the application of the theory at a certain condition. A hypothesis has been issued based on the existing theory, and furthermore the hypothesis will be examined based on the real facts. The research has applied the samples of banking enterprises registered in the Indonesia Stock Exchange for the year of 2013 up to 2016. Tax avoidance is dependent variable. Independent variables are Audit Committee, Proportion of Board of Independent Commissioners. And, controlled variable has used the size and performance of the companies .

\section{Normality Test Data}

Nonparametric statistical test is used to test the data normality. When the probability figure is $<=0.05$, the variable is not normally distributed. But, when the probability figure is $>=0.05$, the variable is normally distributed (Ghozali, 2016). Normality test of the regression model is to examine whether the residual variable of this research has a normal distribution or not. T-test and F-test have assumed that residual value has been getting along with the normal distribution. The more reliable method has identified the probability plotting by comparing the cumulative distribution with the normal distribution. Normal distribution will produce a straight diagonal line, but the residual data plotting will be compared with the diagonal line. 


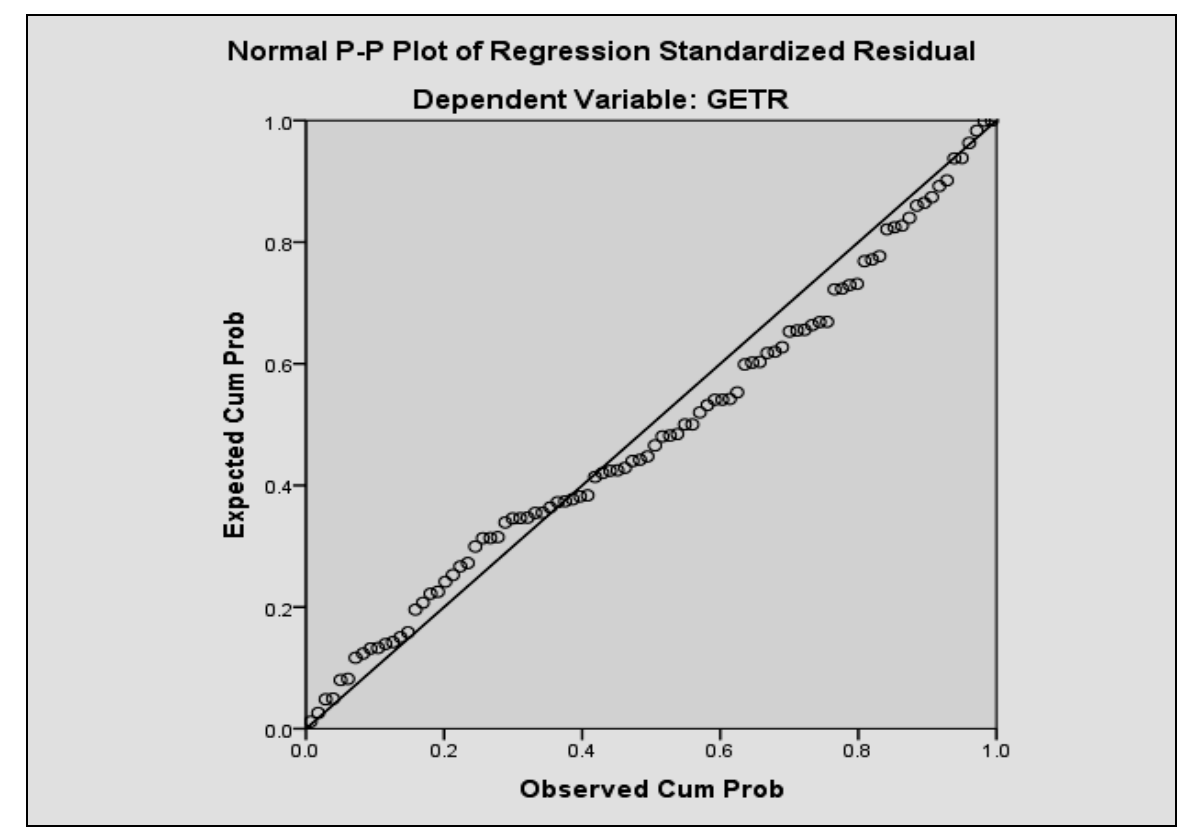

Figure 2: Result of Normality Test

\section{Hypothesis Testing}

The Linear Regression has been applied to anticipate or to predict the correlation between two variables which have made an assumption of a specific function. (linear function)

\section{ANALYSIS}

\section{A. Descriptive Analysis}

The following table has indicated the result of the descriptive statistical output of the processing data using SPSS.

Table 1. Descriptive Analysis

\begin{tabular}{|l|r|r|r|r|r|}
\hline & $\mathrm{N}$ & Minimum & Maximum & Mean & Std. Deviation \\
\hline GETR & 92 & 18,62 & 34,03 & 24,6434 & 3,12264 \\
CA & 92 & 3 & 8 & 4,08 & 1,286 \\
PROP & 92 &, 00 & 100,00 & 54,5937 & 13,69141 \\
INS & 92 &, 00 & 99,96 & 61,1709 & 33,83308 \\
AQ & 92 & 0 & 1 &, 72 &, 453 \\
Valid N (listwise) & 92 & & & & \\
\hline
\end{tabular}

The statistical descriptive on the table 1 has provided general figures of the variables to be studied either the independent variables or the dependent one.

Disclosing the GAAP effective tax rate (GETR), it has identified the minimum value of 18.62, maximum value of 34.03, average value of 24.6434 and the standard of deviation which is 3.12264. Audit Committee (CA) has obtained the minimum value of 3 , maximum value of 8 , average value of 4.08 and the standard of deviation which is 1.286. The proportion of Board of the Independent Commissioners 
(PROP) has obtained the minimum value of 0.00 , maximum value of 100 , average value of 54.5937, and the standard of deviation which is 13.69141. The percentage of the Institutional Ownership (INS) has obtained the minimum value of 0.00 , maximum value of 99.96 , average value of 61.1709 , and the standard of deviation which is 33.83308. Audit Quality (AQ) has obtained the minimum value of 0 , maximum value of 1 , average value of 0.72 , and the standard of deviation which is 0.453 .

\section{B. Full Model Regression}

\begin{tabular}{|c|c|c|c|c|c|c|c|c|}
\hline \multicolumn{9}{|c|}{ Coefficients $^{\mathrm{a}}$} \\
\hline \multirow{2}{*}{\multicolumn{2}{|c|}{ Model }} & \multicolumn{2}{|c|}{$\begin{array}{l}\text { Unstandardized } \\
\text { Coefficients }\end{array}$} & \multirow{2}{*}{$\begin{array}{c}\begin{array}{c}\text { Standardized } \\
\text { Coefficients }\end{array} \\
\text { Beta }\end{array}$} & \multirow[t]{2}{*}{$\mathrm{t}$} & \multirow[t]{2}{*}{ Sig. } & \multicolumn{2}{|c|}{$\begin{array}{l}\text { Collinearity } \\
\text { Statistics }\end{array}$} \\
\hline & & B & $\begin{array}{l}\text { Std. } \\
\text { Error }\end{array}$ & & & & Tolerance & VIF \\
\hline \multirow[t]{5}{*}{1} & (Constant) & 24.605 & 2.746 & & 8.961 & .000 & & \\
\hline & $\mathrm{CA}$ & .618 & .284 & .254 & 2.172 & .033 & .559 & 1.789 \\
\hline & PROP & -.053 & .021 & -.231 & 2.492 & .015 & .894 & 1.118 \\
\hline & INS & -.002 & .009 & -.017 & -.163 & .871 & .742 & 1.348 \\
\hline & $\mathrm{AQ}$ & 1.804 & .698 & .262 & 2.585 & .011 & .748 & 1.337 \\
\hline
\end{tabular}

The Equation of Regression:

GETR $=a+\beta_{1} C A+\beta_{2} P R O P+\beta_{3}$ INS $+\beta_{4} A Q+e$

Which describes:

$\begin{array}{ll}\text { GETR } & =\text { GAAP Effective Tax Rate } \\ \text { CA } & =\text { Total Comitte Audit } \\ \text { PROP } & =\text { Proportion of Board of Commissioners } \\ \text { INS } & =\text { Percentage of the Institutional Ownership } \\ \text { AQ } & =\text { Audit Quality } \\ \mathrm{e} & =\text { Error }\end{array}$

The Result:

GETR $=24.605+0.618 \mathrm{CA}-0.053 \mathrm{PROP}-0.002 \mathrm{INS}+1.804 \mathrm{AQ}+\mathrm{e}$

\section{Hypothesis 1 : Audit Committee has affected Tax Avoidance Practices.}

Based on the test result on table 1 , it has indicated $t_{\text {calculated }}$ value of 2.172 with the significance value of 0.033 or less than $0.05(0.033<0.05)$ Since the significance value or probability test is $<0.05$, hypothesis 1 is accepted. It has indicated that the more members of the audit committee, the more tax avoidance of the company has occurred.

\section{Hypothesis 2 : The Independent Board of Commissioners have affected the practices of Tax Avoidance.}

Based on the test result on the table 1, it has identified $t_{\text {calculated }}$ value of -2.492 and the significance value of 0.015 or less than $0.05(0.015<0.05)$. As the significance value or test probability is 0.05 , then hypothesis 2 is accepted. It has 
indicated that more portion of board of independent commissioners have reduced tax avoidance of the companies.

\section{Hypothesis 3 : The Institutional Ownership has affected Tax Avoidance Practice.}

Based on the test result of the table 1, it has identified the $t_{\text {calculated }}$ value of 0.163 and its significance value of 0.871 or more than $0.05(0.871>0.05)$. As the significance value or probability test is $>0.05$, so that hypothesis 3 is rejected. It has identified that the Institutional Ownership can reduce tax avoidance of the company, however, the effect is not significant.

\section{Hypothesis 4 : Audit Quality has affected Tax Avoidance Practice.}

Based on the test result of the table 1, it has identified $t_{\text {calculated }}$ value of 2.585 and the significance value of 0.011 or less than $0.05(0.011<0.05)$. Due to the significance value or probability test is $<0.05$, hence, hypothesis 4 is accepted. It has indicated that the better audit quality, the more companies have executee tax avoidance.

\section{CONCLUSION}

According to the result of the research, it has concluded that the Audit Committee and Audit Quality have positively affected Tax Avoidance at banking enterprises registered on the Indonesia Stock Exchange. It has figured out the roles of Audit Committee and Audit Quality have been involved in a decision making to execute Tax Avoidance. On the other hand, the roles of the Proportion of Board of Commissioners and the Institutional Ownership have negatively affected Tax. Avoidance.

\section{REFERENCE}

Annisa, N. A., dan Kurniasih, L. (2011). Pengaruh corporate governance terhadap tax avoidance. Jurnal Akuntansi dan Auditing, 8(2), 123-136. (The Effect of Corporate Governance upon Tax Avoidance. Journal of Accountancy and Auditing, 8 (2), 123136.

Antonia, E. (2008). Analisis pengaruh reputasi auditor, proporsi dewan komisaris independen, leverage, kepemilikan manajerial dan proporsi komite audit independen terhadap manajemen laba. Skripsi. Universitas Diponegoro. An Analysis of the effect of auditor reputation, proportion of board of independent commissioners, leverage, the ownership of the managerial and the proportion of the independent audit committee upon the earning management. Scrip.

Darussalam dan Septriadi, D. (2009) Tax Avoidance, Tax Planning, Tax Evasion, dan Anti Avoidance Rule. Ortax. Retrieved from, http://www.ortax.org/.

Davies, A. (2006). Best Practice in Corporate Governance: Building Reputation and Sustainable Succes. England: Gower Publishing Limited.

Dewi, N. N. K., dan Jati, I. K. (2014). Pengaruh karakter eksekutif, karakteristik perusahaan, dan dimensi tata kelola perusahaan yang baik pada tax avoidance di bursa efek Indonesia. E-Jurnal Akuntansi Universitas Udayana. Universitas Udayana. The effect of executives character, company characteristics, and the dimension of good corporate governance on tax avoidance at the Indonesia Stock Exchange. Accountancy E-journal University Udayana. 
Ghozali, I. (2016). Aplikasi Analisis Multivariate dengan Program IBM SPSS 21 Update PLS Regresi. Badan Penerbit Universitas Diponegoro, Semarang. The Application of Multivariate Analysis of the Program IBM SPSS 21 Update PLS Regression. Publishing Department of University Diponegoro, Semarang.

Haruman, Tendi. (2008). Pengaruh Struktur Kepemilikan Terhadap Keputusan Keuangan dan Nilai Perusahaan. Simposium Nasional Akuntansi XI. Pontianak. The Effect of the Ownership Structure upon the Financial Decision and the Company Value. National Accountancy Symposium XI. Pontianak.

Indah, S. N. W. (2010). Pengaruh kompetensi dan independensi auditor terhadap kualitas audit (studi empiris pada auditor kap di Semarang). Skripsi. Universitas Diponegoro. Semarang. The Effect of Auditor Competency and Independency upon the Audit Quality (Empirical study of the auditor kap in Semarang). Scrip.

Jensen, M. C., dan Meckling, W. H. (1976). Theory of the firm : managerial behavior, agency costs and ownership structure. Journal of Financial Economics.

Minnick, K,. dan Noga, T. (2010). Do corporate governance characteristics influence tax management?. Journal of Corporate Finance.

Mulyadi, M. S., Anwar, Y., dan Krisma, E. B. A. D. (2014). Examining corporate governance and corporate tax management. International Journal of Finance \& Banking Studies.

Pohan, H. T. (2008). Pengaruh good corporate governance, rasio tobin's q, perata laba terhadap penghindaran pajak pada perusahaan publik. Jurnal Informasi, Perpajakan, Akuntansi dan Keuangan Publik. Jakarta: Universitas Trisakti. The Effect of good corporate governance, ratio tobin's q, earnings average upon tax avoidance at public companies. Journal of Information, Taxation and Financial Public.

Putra, S. A. (2013). Analisis pengaruh ukuran perusahaan, kepemilikan institusional, dan kepemilikan manajerial terhadap kinerja perusahaan serta dampaknya terhadap nilai perusahaan. Skripsi. Semarang: Universitas Diponegoro. The Analysis about the effect of the company's size, institutional ownership, and managerial ownership upon the performance of the company and its impact on the value of the company. Scrip.

Solomon, J (2007). Corporate governance and accountability. England : John Wiley \& Sons.

Tarjo. (2008). Pengaruh konsentrasi kepemilikan institusional dan leverage terhadap manajemen laba, nilai pemegang saham serta cost of equity capital. Simposium Nasional Akuntansi 11. Pontianak. The effect of institutional ownership concentration and leverage upon the earnings management, the value of shareholders and cost of equity capital.

Timothy, Y. (2010). Effects of corporate governance on tax aggressiveness. An Honours Degree Project. Hong Kong : Hong Kong Baptist University .

Undang-Undang Republik Indonesia. Nomor 28 Tahun 2007 Tentang Ketentuan Umum Dan Tata Cara Perpajakan. ACT of the Republic of Indonesia Number 28 year of 2007 regarding General Regulation and Procedure of Taxation. 
Zhou, Y. (2011). Ownership structure, board characteristics, and tax aggressiveness. Thesis. Lingnan University

Bursa Efek Indonesia. (2001). Peraturan I-A - Keputusan Direksi PT BEJ No.Kep339/BEJ/07-2001. http://www.idx.co.id/. The Indonesia Stock Exchange (2001). Regulation I-A - The Decree of the Director of PT BEJ.

Kementerian Keuangan Republik Indonesia Direktorat Jenderal Pajak. (2013). UndangUndang KUP dan Peraturan Pelaksanaannya. www.pajak.go.id/ The Ministry of Monetary of the Republic of Indonesia Directorate General of Tax (2013). Acts of KUP and the Regulation of the Execution.

Kementerian Keuangan Republik Indonesia. (2014). Anggaran Pendapatan Dan Pembelanjaan Negara. Retrieved from, http://www.kemenkeu.go.id. The Ministry of Monetary of the Republic of Indonesia. (2014). State Budgeting of the Revenue and Spending.

Komite Nasional Kebijakan Governance. (2012). Prinsip dasar pedoman good corporate governance perbankan indonesia. Retrieved from http://www.knkg-indonesia.com/ National Committee of Governance Policy (2012). The Indonesia principles of banking good corporate governance guideline. 
The Accounting Journal of BINANIAGA Vol. 02, No. 02, December 2017

PISSN: $2527-4309$

EISSN: $2580-1481$

This page intentionally be emptied.

Waluyo: The Effect of Good Corporate Governance on Tax Avoidance: Empirical Study of The Indonesian Banking Company

Page : 10 